Matthews, R. E. F. \& Proctor, C. H. (1956). J. gen. Microbiol. 14, 366-370

\title{
Influence of Aliphatic Organic Acids and Metal Ions on Numbers of Local Lesions Produced by a Tobacco Necrosis Virus
}

\author{
By R. E. F. MATTHEWS and C. H. PROCTOR \\ Agricultural Research Council, Virus Research Unit, Molteno Institute, University \\ of Cambridge, and Plant Diseases Division, D.S.I.R., Auckland, New Zealand
}

SUMMARY: Many aliphatic organic acids, when sprayed on the leaves of bean plants, decreased the numbers of local lesions produced following inoculation with a tobacco necrosis virus. Citric and succinic acids were effective only when applied before or during the period of virus establishment. The inhibitory effect of these acids could be annulled by certain metal nitrates.

The susceptibility of a species of host plant to a virus may vary greatly, as judged by the numbers of local lesions produced following inoculation with a standard preparation of virus. Age, nutrition, temperature, illumination and water supply are all known to affect susceptibility. Some of these factors alter the mechanical condition of the leaf, thus affecting the ease with which wounds necessary for virus entry are produced. Others are considered to alter 'host plant metabolism' but the chemical basis for such changes is unknown.

In an attempt to eliminate the daily cycle of variation in susceptibility to tobacco necrosis virus (Matthews, 1953) bean plants were grown under continuous illumination for several days before inoculation. Such plants were found to have a greatly decreased susceptibility to the virus compared with plants grown under natural illumination at about the same temperature. In most experiments no local lesions were produced at all, and no virus was detected in the inoculated leaves 9 days after inoculation. Preliminary analyses of such resistant leaves by chromatographic methods showed no major changes in sugar and amino acid content as compared with normally grown plants. However, there appeared to be a fairly marked increase in the amount of certain aliphatic organic acids. Subsequent tests described here showed that a variety of such acids, when sprayed on the leaves, decreased the number of lesions produced, an effect which was annulled by certain metal nitrates. The results suggest that metal ions may be important for the successful establishment of plant viruses and that one of the factors influencing plant susceptibility may be the balance between metal ions and organic acids in the leaf at the time of inoculation.

\section{METHODS}

The host plant, Phaseolus vulgaris var. Black Prince, and the tobacco necrosis virus were grown and inoculated as described previously (Matthews, 1953). Lesion counts were made 3-5 days after inoculation. Statistical analyses were made on transformed lesion numbers using the transformation $\log _{10}(x+1)$, where $x=$ the number of local lesions per leaf. 


\section{RESULTS}

The effect of treatment with organic acids on numbers of local lesions

Preliminary tests showed that when bean plants were sprayed with a solution of citric acid at $c .0 .01 \mathrm{~N}$ the numbers of local lesions produced by a standard inoculum were greatly decreased. Various organic acids (22 in all) were then tested by a standard procedure. Each acid at a concentration of $0.02 \mathrm{~N}$ was sprayed on the two primary leaves of 12 plants. Four sprays were given-one on each of the 2 days before and after inoculation. Local lesions were counted after 5 days and the numbers compared with appropriate control

Table 1. Effect of organic acids on numbers of local lesions produced by a tobacco necrosis virus in beans

\begin{tabular}{|c|c|c|c|}
\hline Acid & $\begin{array}{c}\text { Decrease in number } \\
\text { of lesions: } \\
\frac{\text { treated }}{\text { control }}\end{array}$ & $\begin{array}{c}\text { Significance of } \\
\text { decrease } \\
(t \text { test }) \\
(\%)\end{array}$ & Leaf damage \\
\hline \multicolumn{4}{|c|}{ Monocarboxylic } \\
\hline Glyoxalic & $0 \cdot 60$ & $5 \cdot 0$ & Nil \\
\hline Pyruvic & 0.54 & $5 \cdot 0$ & Slight \\
\hline Glycollic & $0 \cdot 24$ & $1 \cdot 0$ & Nil \\
\hline Lactic & $1 \cdot 80$ & $5 \cdot 0$ & Nil \\
\hline$\alpha$-Ketobutyric & $0 \cdot 75$ & Not significant & Nil \\
\hline \multicolumn{4}{|c|}{ Dicarboxylic } \\
\hline Oxalic & $0 \cdot 15$ & 1.0 & Marked \\
\hline Malonic & $0 \cdot 32$ & $1 \cdot 0$ & Nil \\
\hline Succinic & 0.06 & $0 \cdot 1$ & Very slight \\
\hline Glutaric & $0 \cdot 14$ & $1 \cdot 0$ & Marked \\
\hline Adipic & 0.03 & $0 \cdot 1$ & Marked \\
\hline Oxaloacetic & $0 \cdot 15$ & $0 \cdot 1$ & Nil \\
\hline$\alpha$-Ketoglutaric & $0 \cdot 36$ & $5 \cdot 0$ & Nil \\
\hline Malic & $0 \cdot 09$ & $0 \cdot 1$ & Nil \\
\hline Fumaric & 0.03 & $0 \cdot 1$ & Moderate \\
\hline Maleic & 0.09 & $0 \cdot 1$ & Nil \\
\hline Mesaconic & 0.08 & $0 \cdot 1$ & Moderate \\
\hline Itaconic & $0 \cdot 10$ & $0 \cdot 1$ & Heavy \\
\hline Citraconic & 0.03 & $0 \cdot 1$ & Moderate \\
\hline \multicolumn{4}{|c|}{ Tricarboxylic } \\
\hline Tricarballylic & $0 \cdot 14$ & $1 \cdot 0$ & Nil \\
\hline Citric & $0 \cdot 21$ & $1 \cdot 0$ & Slight \\
\hline Isocitric & $0 \cdot 13$ & $0 \cdot 1$ & Nil \\
\hline Aconitic & 0.06 & $0 \cdot 1$ & Moderate \\
\hline
\end{tabular}

plants. The mean number of lesions/leaf on 192 control leaves was 46 . The $\mathrm{pH}$ values of the solutions used for spraying ranged from $2 \cdot 7$ to $3 \cdot 6$. The results are summarized in Table 1 . Some acids caused necrotic damage on the leaves. This was readily distinguished from the virus lesions. No correlation was apparent between the $\mathrm{pH}$ value of the solution sprayed, plant damage, and decrease in number of local lesions. The decrease in number of local lesions might have been due to some effect on the virus of the acid which remained on the surface of the leaf. This possibility was eliminated, at least for citric acid, by the following experiment. Bean plants were cut just above soil level and 
the stems placed immediately in various concentrations of citric acid. After $24 \mathrm{hr}$. plants were inoculated with tobacco necrosis virus. Numbers of local lesions produced were (mean of 20 leaves): distilled water, $152 ; 0.00016 \mathrm{~N}$ citric acid, $106 ; 0.00048 \mathrm{~N}$ citric acid, $75 ; 0.0016 \mathrm{~N}$ citric acid, 47. There was a progressive decrease in the numbers of local lesions.

\section{Effect of treatment with metal nitrates on numbers of lesions}

Metal ions are essential for infection by some bacterial viruses. Specific cations may be required, either for adsorption of phage on to sensitive bacteria (e.g. Puck, 1953) or for multiplication steps after phage attachment has taken place (Adams, 1949; Fildes, Kay \& Joklik, 1951); no such evidence is available

Table 2. Effect of succinic acid, magnesium nitrate and calcium nitrate on number of local lesions produced by tobacco necrosis virus in beans

\begin{tabular}{|c|c|c|c|}
\hline \multirow[b]{2}{*}{ Spraying solution } & \multirow[b]{2}{*}{$\begin{array}{l}\text { No. of local } \\
\text { lesions (mean } \\
\text { of } 16 \text { leaves) }\end{array}$} & \multicolumn{2}{|c|}{$\begin{array}{c}\text { Significance of difference } \\
\text { from }\end{array}$} \\
\hline & & $\begin{array}{c}\text { Control } \\
(\%)\end{array}$ & $\begin{array}{l}\text { Sprayed with } \\
\text { acid only } \\
(\%)\end{array}$ \\
\hline Unsprayed control & 19 & - & $0 \cdot 1$ \\
\hline $\mathrm{Mg}\left(\mathrm{NO}_{3}\right)_{2}, 0.001 \mathrm{M}$ & 27 & $1 \cdot 0$ & $0 \cdot 1$ \\
\hline $\mathrm{Mg}\left(\mathrm{NO}_{3}\right)_{2}, 0.01 \mathrm{M}$ & 36 & $0 \cdot 1$ & $0 \cdot 1$ \\
\hline Succinic acid, $0.01 \mathrm{~N}$ & 8 & $0 \cdot 1$ & - \\
\hline $\mathrm{Mg}\left(\mathrm{NO}_{3}\right)_{2}, 0.001 \mathrm{M}+$ succinic acid, $0.01 \mathrm{~N}$ & 13 & $5 \cdot 0$ & $0 \cdot 1$ \\
\hline $\mathrm{Mg}\left(\mathrm{NO}_{3}\right)_{2}, 0.01 \mathrm{M}+$ succinic acid, $0.01 \mathrm{~N}$ & 24 & None & $0 \cdot 1$ \\
\hline Unsprayed control & 84 & - & $0 \cdot 1$ \\
\hline $\mathrm{Ca}\left(\mathrm{NO}_{3}\right)_{2}, 0.001 \mathrm{M}$ & 77 & None & $0 \cdot 1$ \\
\hline $\mathrm{Ca}\left(\mathrm{NO}_{3}\right)_{2}, 0.01 \mathrm{M}$ & 70 & None & $0 \cdot 1$ \\
\hline Succinic acid, $0 \cdot 01 \mathrm{~N}$ & 20 & $0 \cdot 1$ & - \\
\hline $\mathrm{Ca}\left(\mathrm{NO}_{3}\right)_{2}, 0.001 \mathrm{M}+$ succinic acid, $0.01 \mathrm{~N}$ & 37 & $1 \cdot 0$ & $0 \cdot 1$ \\
\hline $\mathrm{Ca}\left(\mathrm{NO}_{3}\right)_{2}, 0.01 \mathrm{M}+$ succinic acid, $0 \cdot 01 \mathrm{~N}$ & 49 & $1 \cdot 0$ & $0 \cdot 1$ \\
\hline
\end{tabular}

for plant viruses. However, many organic acids are known to chelate metal ions. This suggested that if metal ions were essential for plant virus establishment organic acids might act, at least in part, by sequestering such ions. To test the effect of metal ions on the production of local lesions, plants were sprayed in the 4th and 2 nd day before inoculation with an organic acid, and on the 3rd day and the day before inoculation with a metal nitrate. The results of one such experiment are summarized in Table 2. Both calcium and magnesium nitrates partially or completely annulled the effect of succinic acid. Magnesium nitrate alone at $0.01 \mathrm{~m}$ increased the number of local lesions about twofold. Various other nitrates were tested in experiments like that recorded in Table 2. Potassium and ammonium nitrates had no effects. In some experiments sodium nitrate significantly reduced the effect of succinic and citric acids. Caesium, barium and aluminium nitrates applied alone significantly increased the number of local lesions and also reduced the inhibitory effect of succinic acid. Zinc nitrate alone caused a striking reduction in number of lesions, as has been found previously for tobacco mosaic virus (Weintraube, Gilpatrick \& Willison, 1952). 
The extent to which numbers of local lesions were decreased by citric and succinic acids varied in different experiments, as did the annulling effect of metal ions. Until the factors affecting this variation are understood it is not possible to give firm comparative figures for the effects of different metals.

Age of plant does not appear to affect the activity of succinic acid. Plants in four age groups, ranging from those in which the leaves were not fully expanded to plants approaching senescence, gave the following figures for the ratio of number of local lesions on succinic acid treated plants : control, namely $0 \cdot 15,0 \cdot 13,0 \cdot 14,0 \cdot 13$ in order of increasing age of plant.

\section{The effect of time of treatment in relation to time of inoculation}

Preliminary experiments showed that a single treatment with an organic acid was effective when applied 1 or 2 days before inoculation, but ineffective when applied 1 day after inoculation. The effect of single treatments at times close to the time of inoculation was then examined. Since spraying with water alone just before inoculation caused a marked decrease in numbers of local lesions, a control set of plants was sprayed with water for each time tested. The results of one experiment are summarized in Table 3.

Table 3. Effect of $0 \cdot 02 \mathrm{~N}$ succinic acid applied at various times before and after inoculation

\begin{tabular}{|c|c|}
\hline $\begin{array}{l}\text { Time of spraying in } \\
\text { relation to time of } \\
\text { inoculation }\end{array}$ & $\begin{array}{c}\text { Ratio of number } \\
\text { local lesions: } \\
\text { acid sprayed } \\
\text { water sprayed }\end{array}$ \\
\hline $15 \mathrm{~min}$. before & 0.14 \\
\hline Immediately before & $0 \cdot 28$ \\
\hline Immediately after & $0 \cdot 50$ \\
\hline 15 min. after & 0.56 \\
\hline $30 \mathrm{~min}$. after & $0 \cdot 56$ \\
\hline 45 min. after & $0 \cdot 67$ \\
\hline $60 \mathrm{~min}$. after & 0.55 \\
\hline $1.5 \mathrm{hr}$. after & 0.71 \\
\hline $2 \mathrm{hr}$. after & 0.82 \\
\hline
\end{tabular}

A treatment immediately before inoculation decreased the number of lesions more than a treatment immediately after inoculation. In various experiments treatments with succinic or citric acids after about 2-4 hr. were ineffective.

\section{DISCUSSION}

The fact that the decrease in numbers of lesions by organic acids was annulled by metal ions does not necessarily imply a close connexion between action of these two types of compound. However, some organic acids are known to sequestrate metal ions through the formation of chelate compounds. The simplest explanation for the effects described here is to assume that the tobacco necrosis virus requires certain metal ions for successful establishment and that the organic acids inhibit this process by decreasing the concentration of 
available metal ion. However, in preliminary tests the well-known chelating agent, ethylenediamine tetra-acetic acid caused no greater decrease in lesion number than did citric and succinic acids.

With bacterial viruses it is possible to control the concentration of compounds in the medium in which virus establishment occurs. No such control is possible with plant leaves. The variation in the magnitude of the effects we have observed may well be due to natural variation in the state of the plant with respect to metal ions and organic acids or other chelating compounds at the time of inoculation. Some of the acids on entering the leaf are probably rapidly metabolized. In addition, there is no reason to suppose that all the acids listed in Table 2 exert their inhibitory effect in the way suggested above. For these reasons no correlation can be expected between data such as are given in Table 1 and the chelate stability constants for the various acids with calcium and magnesium (Martell \& Calvin, 1952). It may be of interest from the point of view of virus control that a class of compound which must be universally present in susceptible leaves can in increased concentration inhibit virus establishment.

\section{REFERENCES}

Adams, M. H. (1949). The calcium requirement of coliphage T 5. J. Immunol. 62, 505.

Fildes, P., KAY, D. \& Joklik, W. K. (1951). Divalent metals in phage production in Nature of Virus Multiplication. Symp. Soc. gen. Microbiol. 2, 194.

Martell, A. E. \& Calvin, M. (1952). Chemistry of the Metal Chelate Compounds. New York: Prentice Hall.

Matthews, R. E. F. (1953). Factors affecting the production of local lesions by plant viruses. I. The effect of time of day of inoculation. Ann. appl. Biol. 40, 377.

Puck, T. T. (1953). The first steps of virus invasion. Cold Spr. Harb. Symp. quant. Biol. 18, 149.

Weintraube, M., Gilpatrick, J. D. \& Willison, R. S. (1952). The effect of certain water-soluble compounds on virus infection. Phytopathology, 42, 417. 